\title{
Spatial Assessment of Water Quantity Stress in Sultanate of Oman Provinces: A GIS Based Analysis of Water Resources Variability
}

\author{
Talal Al-Awadhi ${ }^{1}$, Shawky Mansour ${ }^{2}$ \\ ${ }^{1}$ Department of Geography, College of Arts and Social Sciences, Sultan Qaboos University, Muscat, Oman \\ ${ }^{2}$ Department of Geography and GIS, Faculty of Arts, Alexandria University, Alexandria, Egypt \\ Email: alawadhi@squ.edu.om, gisshawky@yahoo.com
}

Received 20 October 2015; accepted 17 November 2015; published 20 November 2015

Copyright (C) 2015 by authors and Scientific Research Publishing Inc.

This work is licensed under the Creative Commons Attribution International License (CC BY). http://creativecommons.org/licenses/by/4.0/

(c) (7) Open Access

\begin{abstract}
Water quantity planning and management require understanding of spatial variations of water catchment availability. Several environmental indicators are associated with water quantity such as flood occurrence, drought severity, seasonal supply and groundwater stress. Analyzing water stress at national geographic scale is crucial to detect and explore geographic shortage of water resources at national scale. In this study, Geographical Information Systems (GIS) techniques were employed to analyze the spatial variations of water scarcity across Sultanate of Oman provinces. For this main objective, various spatial and attribute datasets were prepared. Many variables were selected based on their importance and correlation with water quantity. GIS overlay function then was used to produce maps for each water indicator. This was followed by employing raster zonal statistics to aggregate the values of each catchment area within each province. The findings of this analysis indicated that significant spatial variation was found among Omani provinces in terms of water quantity stress and its determinants. The most important factors affecting the water quantity stress were drought severity and flood occurrence. Furthermore, physical risk of water quantity was higher in Mascut and Dhofar provinces while it was moderate in Al-Batinah, A'Dakhiliyah and Al-Wusta. Lower risk of water quantity was observed in A'Sharqiyah, Masandam, and A'Dhahriah provinces. Thus, in order to mitigate the impacts of water scarcity on agriculture, cultivation and domestic usages, policy makers in water sector should include spatial strategies for water resource maintain and allocation.
\end{abstract}

\section{Keywords}

GIS, Spatial Assessment, Water Quantity, Omani Provinces

How to cite this paper: Al-Awadhi, T. and Mansour, S. (2015) Spatial Assessment of Water Quantity Stress in Sultanate of Oman Provinces: A GIS Based Analysis of Water Resources Variability. Journal of Geographic Information System, 7, 565578. http://dx.doi.org/10.4236/jgis.2015.76045 


\section{Introduction}

Scarcity of water quantity is one of the most environmental hazards that impact several countries particularly in arid and semiarid regions. Water quantity stress globally is much related to various physical and environmental factors such as rainfall, surface upstream system, groundwater, floods and drought. Such these factors are important determinants in characterizing water scarcity map in any country [1]. During the last two decades, much research has been done in the field of water resources. Most studies focused mainly upon addressing global hydrology of water resources, spatial or temporal variation within river basins and groundwater vulnerability [2][4]. Water scarcity assessment was used to investigate the available freshwater for human usage. However, most of these studies were conducted globally and due to large scale [5]. Research on differences in water scarcity at national scales is very rare.

It was estimated that $60 \%$ of global population may challenge water scarcity by 2025 and most of scare water countries are located in arid and semi-arid zones especially in the Middle East and North Africa [6]. Environmental constraints and climate change have increased the crises of water scarcity in arid and semi-arid countries. Thus, considerable annual decline of freshwater supply has been observed. Population growth, global warming, drought, poor rainfall and environmental degradation within arid countries lead to more decline in water resources and national pressures. Therefore, new approaches for water management and planning are required [7] [8]. The existing water supplies for those countries are insufficient to meet their population demand in several domains (industrial, agricultural, and domestic). However, water stress across arid and semi-arid countries is heterogeneous and each country should adapt different strategies and plans for water risk management [9].

Integration of GIS and hydrological modelling in analyzing watershed-based resources management is a successful approach especially in allowing for various measures to be included in the analysis [10]. Hydrological watershed model was developed (Fortin et al., 2001) based on GIS and remote sensing datasets. Investigating irrigated agriculture is a continuing concern within employing Soil and Water Assessment Tool (SWAT) as a GIS based hydrological model. This model was an important method in analyzing of the hydrological processes and variables variation such as rainfall, soils, and crops grown across different geographic units [11]. There is evidence that SWAT model, through GIS interface, plays a crucial role in water quantity and quality management [12]. Modelling of river systems and dams is generally used in addressing water resources allocation management particularly for sector of agricultural production [13]. Preliminary work on assessment of using GIS open source software in water resource management in the developing countries was undertaken by Chen et al. [14]. The most performed techniques and methods by water management community using open software packages were contour maps, flow lines under thematic mapping criteria, producing TIN and DEM, slope and aspect calculation and terrain analysis. Parish et al. [15] discussed the impacts of water stress on population and the insufficient freshwater available for people worldwide. Analyzing the interrelationship between population and water resources relevant to climate change was done. Adapting a simulation methodology, estimates of per capita water availability were aggregated by watershed and political unit. The observed increasing water stress is essentially resulting from the growth of water domestic use, and the increasing rate of water withdrawal [16].

GIS and spatial analysis techniques fundamentally have potential roles in contributing to the instruments of water stress applications in different disciplines such as hydrology, climatology, agriculture, geography and water resources. For instances, a conceptual GIS data model was created and used to assess river basin water allocation through connecting GIS capabilities to water management policies [17]. Likewise, constructing indices through weighting and combination of indicators are also applicable as measures of spatial variation of catchment areas. Using image and vector data, various components are integrated to provide a single metric and could be used to rank sub-catchment areas [18]. Geospatial indicators were developed to evaluate water scarcity in Africa Vörösmarty et al. [19] and aquifer vulnerability index was introduced by Stempvoort et al. [20]. GIS tools were used to produce maps for $3100 \mathrm{~km}^{2}$ area along the Saskatchewan-Alberta boundary. The index is considered an effective method in defining groundwater protection areas and screening locations for land use selection. Indices construction based methods on the field of water management provide a means of measuring water stress in particular for agricultural irrigation [21].

Evidences on the scarcity of groundwater in the Middle East Countries were reported [22]. For instances in Iraq, several factors such as drought, global warming, population growth cause shortage in water resources and lead to a gap between demand and supply rates. Analysis of the shortages of water resources in the United Arab 
Emirates (UAE) was carried out by Murad [23]. He investigated the relationship between scarcity of groundwater production and factors such as rainfall, pumping, and agricultural activities. The challenges for sustainability of water resources in UAE were highlighted as the location in the arid zone, population growth, groundwater deterioration and higher water consumption in agriculture, domestic and industrial activities. Apart from [24], there is a general lack of research in water resources of the Gulf Cooperation Council (GCC) countries. The study highlighted the lack of renewable water resources and addressed issues of water availability, demands, and utilization and consumption sectors. Another important study about water resources of Oman [25] pointed out that the Aflaj systems provide more than 60 percent of the potable water supply in the Sultanate of Oman and almost irrigate 55 percent of the cropped area.

Although much of the research up to now has been carried out in water resources using GIS and remote sensing techniques, little known about analyzing variations of water quantity at national scale within one country. This paper provides a clear GIS approach to explore, assess and examine the spatial variation of water quantity and exposure to changes of environmental water supplies (e.g. rainfall, floods) among Omani provinces. The study also aims to identify provinces with the higher and lower rates of water withdrawal and availability that significantly determine water stress levels. The overall structure of the study is as follows: following the current section that serves as introduction, highlights the related works and laying out the theoretical dimensions of the research, next Section 2 represents the datasets focusing on study area, sources of spatial and attribute data. Section 3 describes the employed GIS and statistical methods. The findings and discussion are depicted in Section 4 followed by Section 5 which presents the conclusion and recommendations of the study.

\section{Data and Methods}

\subsection{Study Area}

The Sultanate of Oman is located on the south eastern corner of the Arabian Peninsula, along the Gulf of Oman and the Arabian Sea, from the Strait of Hormuz in the North to the borders of Yemen in the South. The Sultanate is bordered by the Republic of Yemen in the south, the United Arab Emirates (UAE) in the north and west and the Kingdom of Saudi Arabia in the west (Figure 1). The area size of the Sultanate is almost 309,500 kilometer squares including several islands. According to the national center for statistics and information, the total population of Oman is 4,213,982 in August 2015.

Oman lies between latitudes $16^{\circ} \mathrm{N}$ and $28^{\circ} \mathrm{N}$, and longitudes $52^{\circ} \mathrm{E}$ and $60^{\circ} \mathrm{E}$. A vast gravel desert plain covers most of central Oman, with mountain ranges along the north (Al Hajar Mountains) and southeast coast, where the country's main cities are also located: the capital city Muscat, Sohar and Sur in the north, and Salalah in the south.

The climate of Oman is hot and dry in the interior regions while it is humid along the coastal areas. Overall, the country receives little rainfall where the annual rainfall in Muscat averages $100 \mathrm{~mm}$, falling mostly in January. The mountain areas receive much higher rainfall especially in Al Hajar Mountains. While Dhofar Mountains receives seasonal rainfall (from late June to mid-September) as a result of the monsoon winds from the Indian Ocean, saturated with cool moisture and heavy fog. The higher parts of the Jabal Akhdar receive more rainfall compared with other parts of the country and probably exceed $400 \mathrm{~mm}$ (15.7 in).

\subsection{Datasets}

The local scale analysis presented in this paper relies on using attribute data from Aqueduct Water Stress Projections which were conducted by World Resource Institute (WRI) in Washington DC, USA. The dataset includes several indicators of change in water quantity and quality such as water supply, water demand, water stress, and seasonal variability. The spatial data are in the form of ESRI shapefile covering catchment areas of Oman. The catchment area polygon layer contains a total of 106 features. The attribute variables that were joined to the spatial layer including water quantity indicators and they are summarized in Table 1 . The definition of each indicator is explained here based on the calculation made by WRI [26].

\section{Methodology}

\subsection{GIS Methods}

To assess the spatial variation of water quantity stress across Omani Provinces and apply geostatistical calcula- 


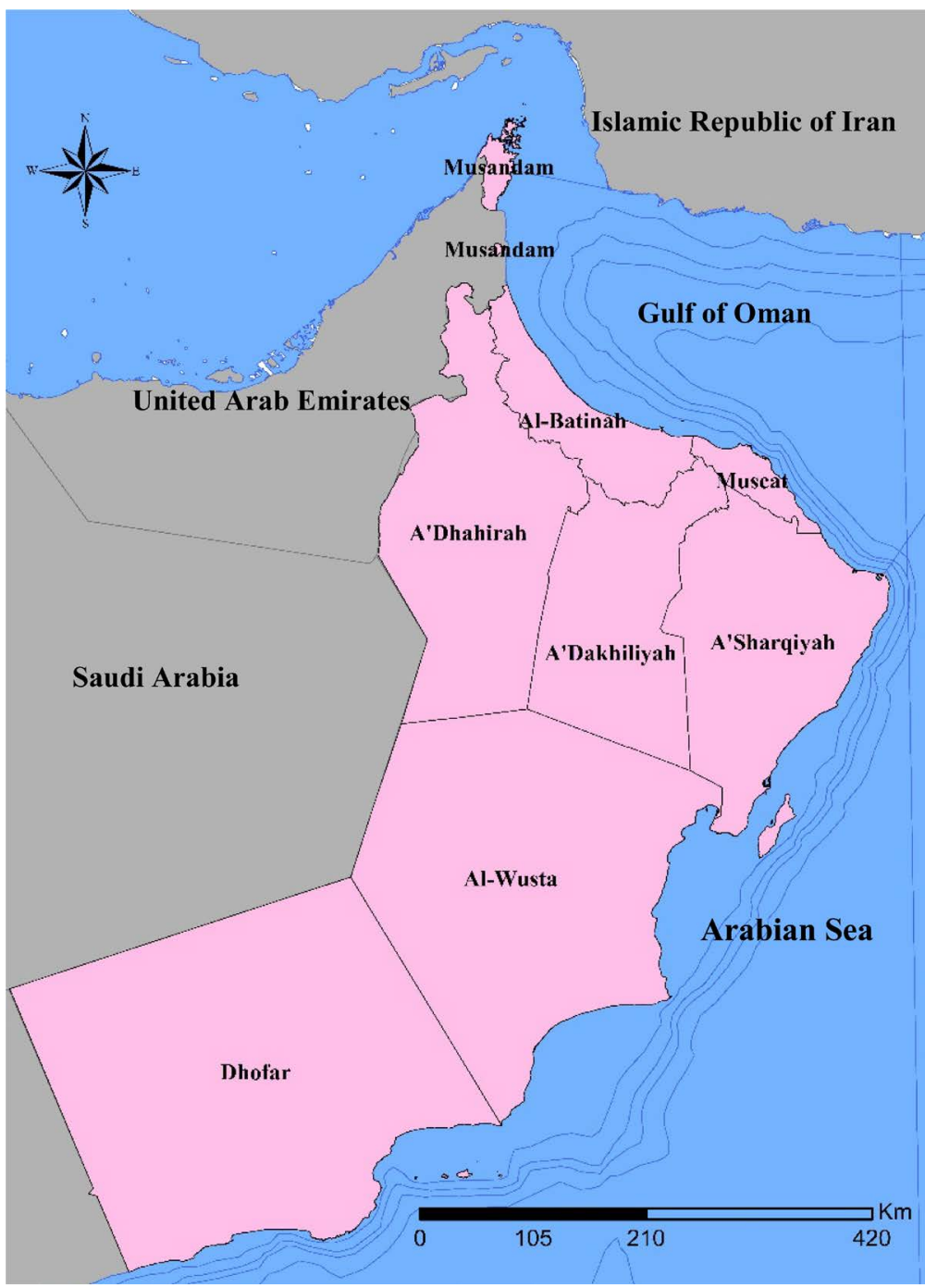

Figure 1. Location of sultanate of Oman.

Table 1 . The selected water quantity indicators.

\begin{tabular}{|c|c|c|c|}
\hline & Indicator & Definition & Calculation \\
\hline 1 & $\begin{array}{l}\text { Available blue } \\
\text { water }\left(\mathrm{m}^{3}\right) \text { BA }\end{array}$ & $\begin{array}{l}\text { The total amount of water available for a catchment area } \\
\text { before any are satisfied. }\end{array}$ & $\begin{array}{l}\text { Recording the available amount of water in cubic } \\
\text { meter. }\end{array}$ \\
\hline 2 & $\begin{array}{l}\text { Total withdrawal } \\
\qquad\left(\mathrm{m}^{3}\right)\end{array}$ & $\begin{array}{l}\text { The total amount of water removed from fresh water } \\
\text { sources for human use. }\end{array}$ & $\begin{array}{l}\text { Recording the total amount of water in cubic } \\
\text { meter. }\end{array}$ \\
\hline 3 & $\begin{array}{c}\text { Seasonal } \\
\text { variability (SV) }\end{array}$ & $\begin{array}{l}\text { Measures variation of water supply among months of the } \\
\text { year. }\end{array}$ & $\begin{array}{l}\text { Standard deviation divided by mean of total } \\
\text { supply calculated using the monthly mean. }\end{array}$ \\
\hline 4 & $\begin{array}{l}\text { Flood occurrence } \\
\text { (FO) }\end{array}$ & The number of recorded floods from 1985 to 2011. & Recording number of floods 1985-2011. \\
\hline 5 & $\begin{array}{l}\text { Drought severity } \\
\text { (DS) }\end{array}$ & $\begin{array}{l}\text { Measures the average length of drought times from } 1901 \text { to } \\
2008 .\end{array}$ & Mean length $\times$ dryness. \\
\hline 6 & $\begin{array}{l}\text { Baseline water } \\
\text { stress (BWS) }\end{array}$ & $\begin{array}{l}\text { The total annual water withdrawal expressed as the } \\
\text { percentage of the total annual available water. }\end{array}$ & $\begin{array}{l}\text { Withdrawals divided by available flow (higher } \\
\text { score indicate higher competition among user). }\end{array}$ \\
\hline 7 & $\begin{array}{l}\text { Weight physical } \\
\text { risk quantity }\end{array}$ & $\begin{array}{l}\text { The physical risk related to water quantity including } \\
\text { indicator of availability and variability ( e.g. drought and } \\
\text { floods). }\end{array}$ & $\begin{array}{l}\text { Setting a specific weight for each quantity } \\
\text { indicator based on its important and relevance. }\end{array}$ \\
\hline
\end{tabular}


tion, GIS methods were used within ArcGIS 10.2 to aggregate the values of each cell in catchment area into the polygon (province) to which fall within. The method procedures were applied as follows:

- A spatial layer of Omani Provinces overlaid with the catchment areas to explore the spatial distribution of water catchments across Omani administrative boundaries.

- Converting the catchment area polygons to a raster layer using the tool feature to raster where the input field type is the indicator values of the input feature attribute table.

- Using the output of catchment areas in the form of raster layer as an input for zonal statistics method which calculates statistics on values of a raster layer (catchment raster) within zones of another dataset (provinces).

- To generate attribute data for each province from the raster layer, zonal statistics as table was used. The output then is a statistical summary for each province.

The advantage of using the above method is particularly in using the output attributes that can be joined to the administrative zones as input for various geo-statistical calculation and GIS modeling. For instances, using global or local models to predicate the structure of spatial pattern of water quantity stress as dependent variable and the relationship between this variable and other determinants.

\subsection{Multiple Linear Regression}

To evaluate the relationship between water quantity risk and two environmental measures (drought severity and seasonal variation of water supply) as explanatory variables, we implemented a multiple regression model. The multiple regression analysis is mainly applied to produce an equation which predicts a dependent variable using two or more independent variables. This equation has the form as follows:

$$
y=b_{0}+b_{1} x_{1}+b_{2} x_{2}+\ldots+b_{n} x_{n}+\varepsilon_{i}
$$

where $y$ is the dependent variable which is the estimated values of water quantity risk at province $j$.

$b_{0}$ to $b_{n}$ are the regression model coefficient determined by the analysis.

$x_{1}$ to $x_{n}$ are the explanatory variables (drought severity and seasonal variation of water supply) that predict the independent variable.

$\varepsilon_{i}$ is the residual error or the difference between observed and predicted values of the dependent variable at province $j$.

\section{Results and Discussion}

\subsection{Spatial Variation of Water Quantity}

It is not sufficient to explore and investigate issues of water quantity, supply and demand based on global trend. Local decisions on water use are important to manage effectively water accessibility and availability in different domains within every country. We begin with an analysis of water quantity availability and withdrawal. The amount of water in both indicators was converted from cubic meter to million cubic meter for ease detection of geographic variations. Water quantity can be defined as the total volume of all water types including both surface and underground water that are used in various domains such domestic, agricultural and industrial sectors. This indicator describes the water quantity available in each catchment area (Figure 2). For better understanding of water quantity available in Sultanate of Oman, we attempts to describe the water quantity situation at subnational geographic scale. At global level (the whole country), the regional disparity is not very large. The country can be classified into two regional zones, one zone with higher volume of water quantity in the western and southern western prats while the other in the eastern and northern parts where the water quantity volume is lower. However, based on province scale, it seems that there is a clear subnational difference in the available water quantity across Omani provinces. Figure 2 shows substantial higher volume of water quantity in Dhofar and A'Dhahriah provinces ( $<400$ million cubic meters). A slightly higher volume of water quantity also is found in Al-Wusta province ( $<300$ million cubic meters). The water quantity volume in A'Dakhiliyah and A'Sharqiyah provinces comes in the middle class (290 to 260 million cubic meters).The lowest volume of water quantity is observed in Muscat, Al-Batinah and Musandam provinces (less than 50 million cubic meters).

The water withdrawal indicator refers to the sum of the reported total annual of used water in different sectors (e.g., domestic, agricultural, industrial and others). This indicator is potentially associated with human activities and water usage and consumptions. The Spatial pattern of water withdrawal across Sultanate of Oman varies by catchment area and province (Figure 3). The highest water withdrawal can be identified in the northern and 

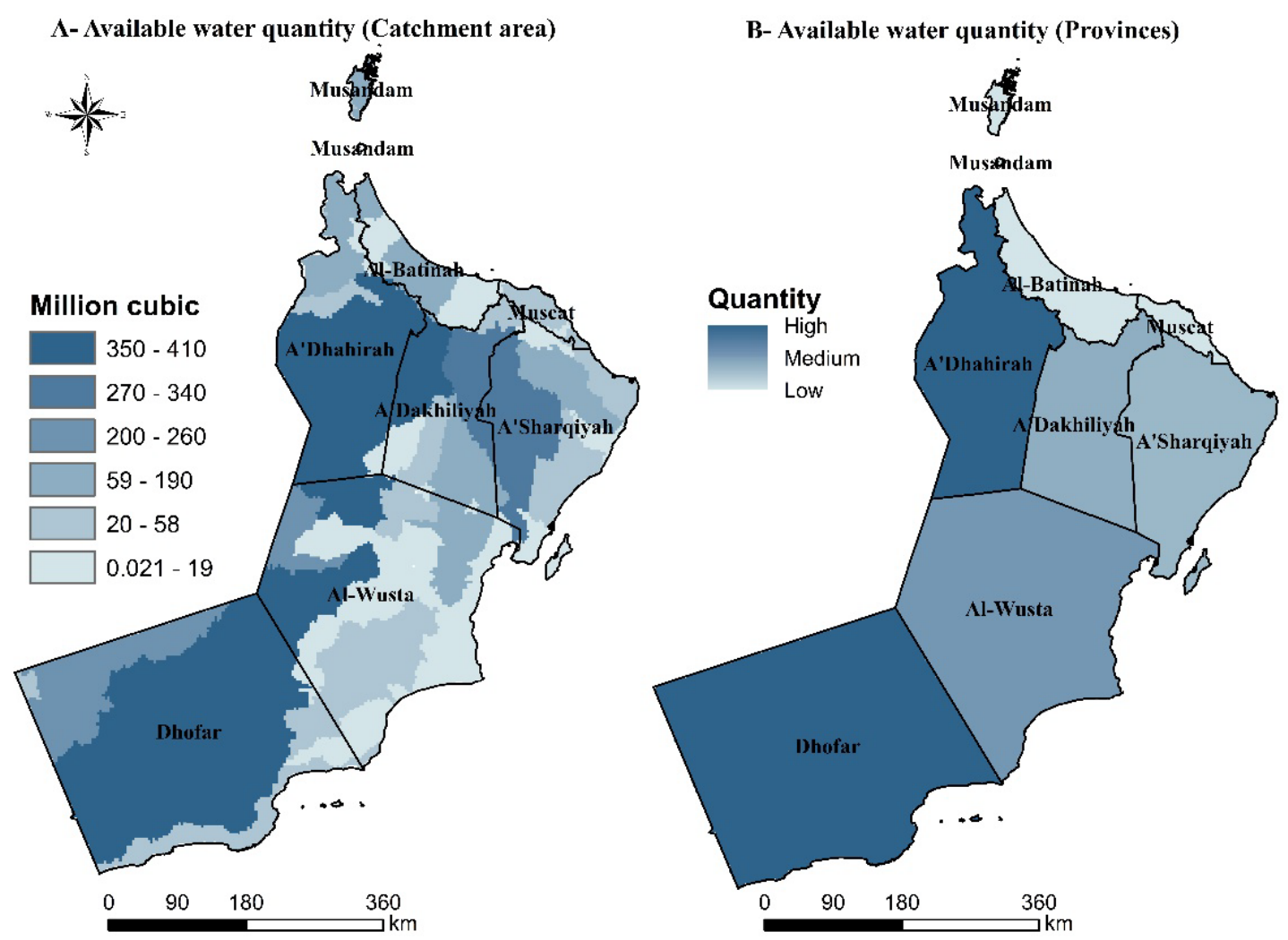

Figure 2. Variation of water availability by catchment area and province.

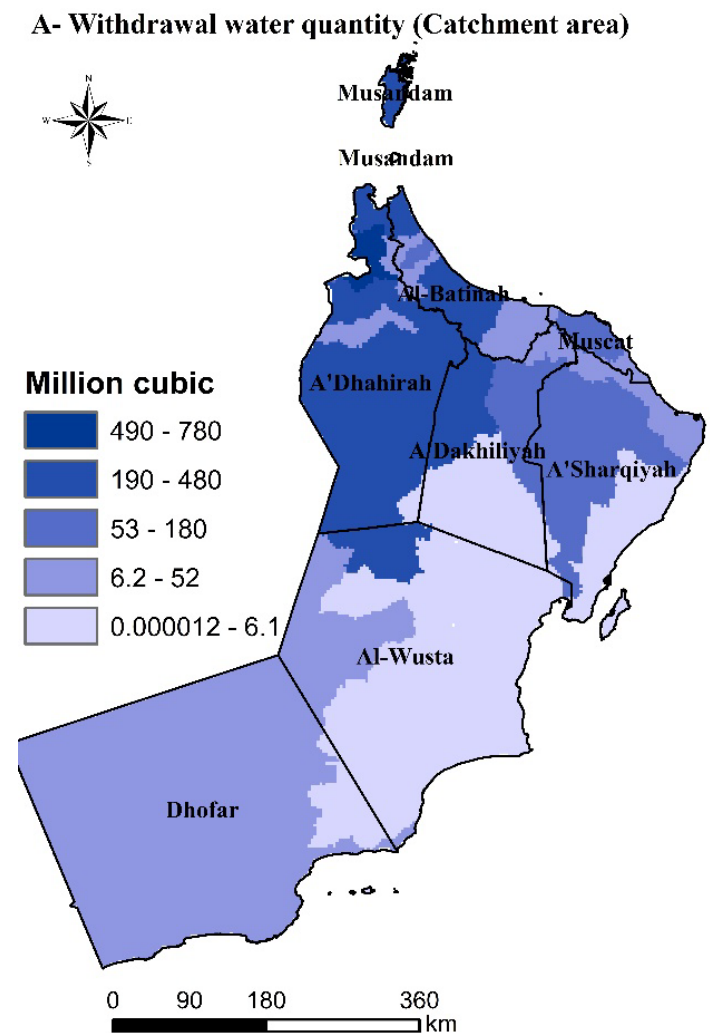

B- Withdrawal water quantity (Provinces)

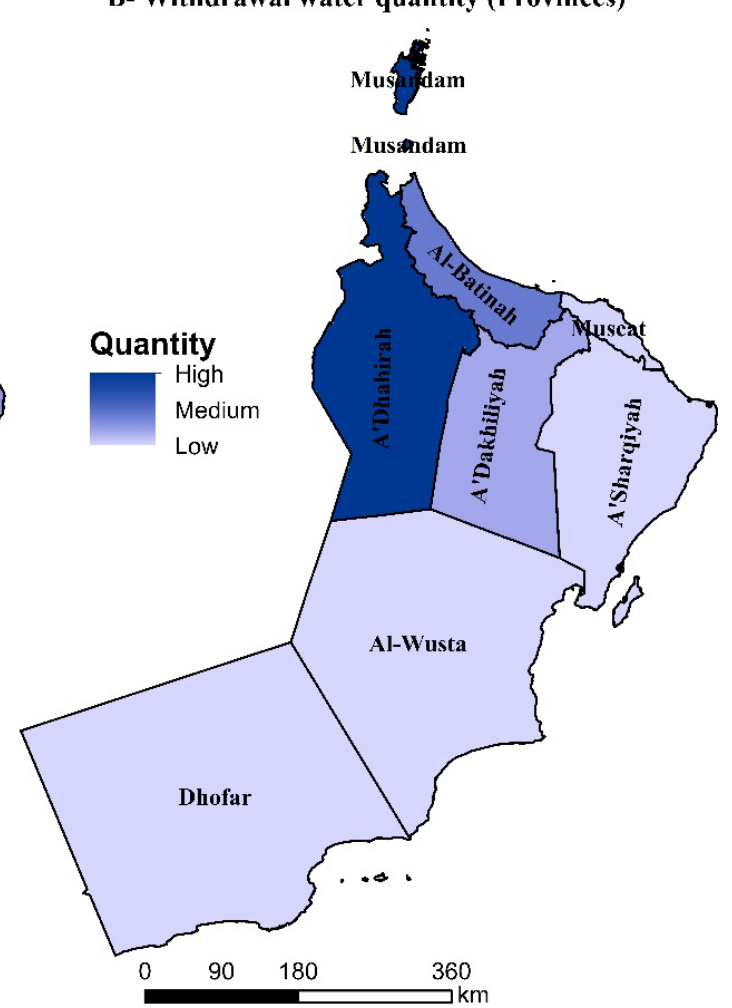

Figure 3. Variation of water withdrawal by catchment area and province. 
eastern areas particularly in A'Dhahriah, Al-Batinah and Musandam provinces. A'Dakhiliyah, Dhofar and A'Sharqiyah show moderate level of water withdrawal. Interestingly, Muscat and Al-Wusta present the lowest water withdrawal values compared to other provinces and this can be investigated as the consumed water volume used mainly in the domestic sector which consumes lower quantity in comparison with irrigation and agriculture sectors. Thus a decrease in water withdrawal can be found where agriculture activities are limited.

The balanced between water consumption and availability can be evaluated using these two indicators. Figure 4 provides a comparison between water availability and withdrawal in Omani provinces. There is a notable and distinct difference in the gap between water consumption (withdrawal) and availability at subnational scale. The gap is bigger in Al-Batinah and Musandam provinces where consumed water values are higher than the available water quantity. Similarly, the consumed volume of water is also greater than the available in Muscat province.It is apparent that A'Dakhiliyah and A'Dhahriah provinces represent balanced values of water withdrawal and consumption. Conversely, the available water volume is higher than withdrawal values in Dhofar, A'Dakhiliyah, Al-Wusta and A'Sharqiyah.

\subsection{Spatial Variation of Water Quantity Indicators}

\subsubsection{Seasonal Variability Indicator}

Seasonal and annual variation of climatic variables (e.g., temperature, rainfall) is the most important factors influencing surface water supply. Understanding the impacts of climate variability on water quantity is essential for measuring geographic variations of water supply. Therefore, water quantity assessment requires adequate investigation of variables of seasonal climate conditions. The term seasonal variability refers to the estimated variation of water supply during year months specifically to measure differences in natural water surfaces. The spatial seasonal variability varies at subnational level (Figure 5). Higher variation of water supply was found in Al-Batinah, Muscat and Musandam provinces. Moderate seasonal variability was observed in Dhofar and, Al-Wusta while the pattern of less seasonal variations was observed in the middle areas particularly A'Dakhiliyah, A'Sharqiyah and A'Dhahriah. According to the spatial distribution of seasonal variability based on catchment areas, lower number of catchments showed higher variation in water supply specifically in the far east of the

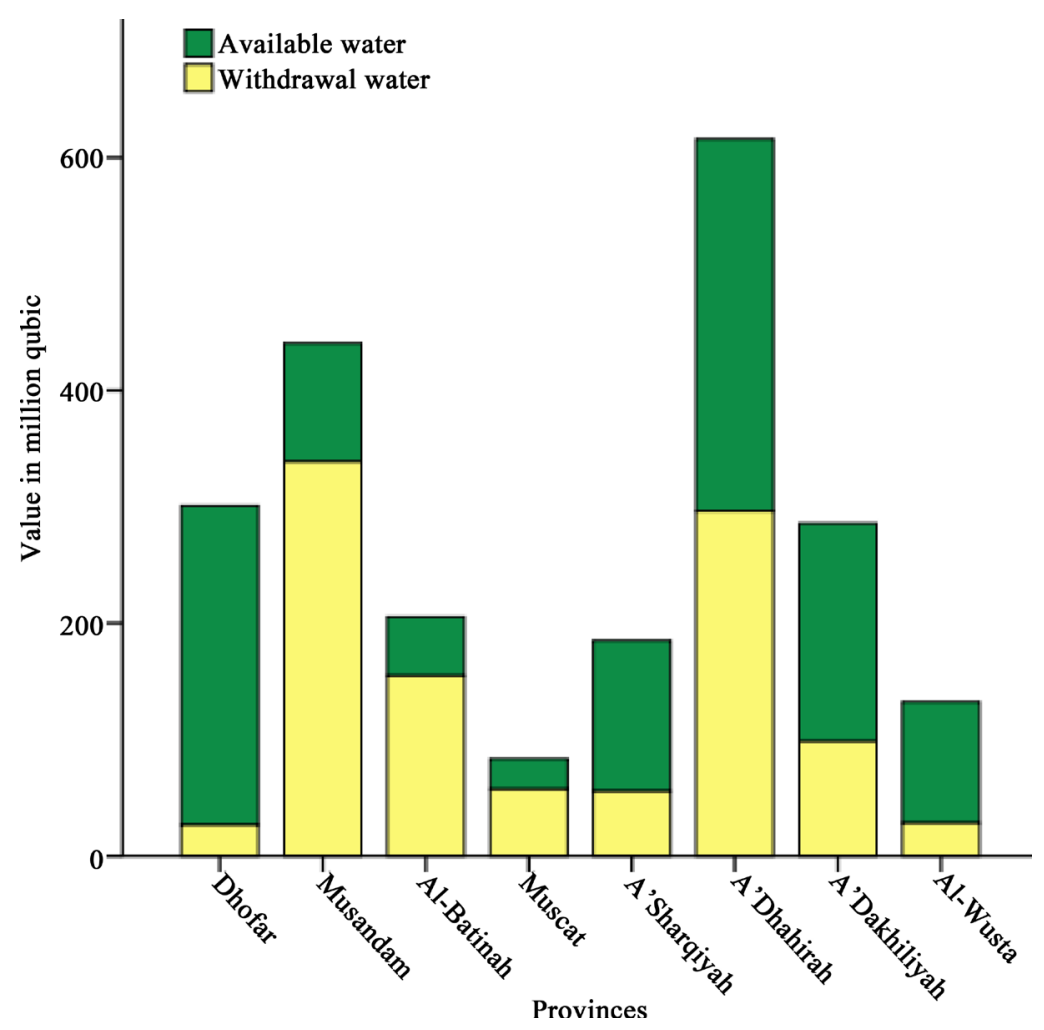

Figure 4. Comparison between the quantity of water availability and withdrawal among Omani provinces. 

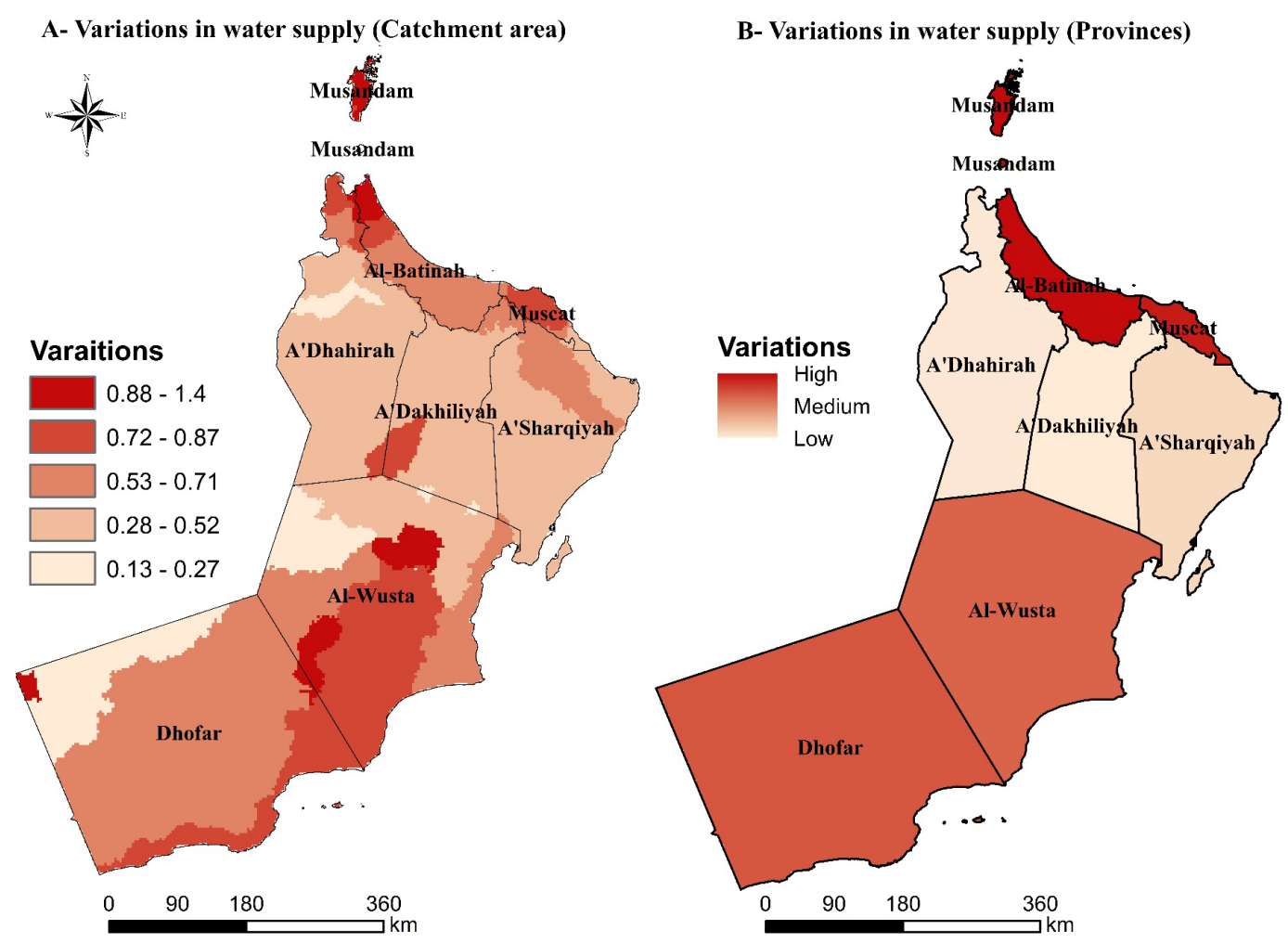

Figure 5. Variation of water supply (seasonal variability) by catchment area and province.

country (e.g., in Al-Batinah and Masandam). Similarly, some of catchment basins that are located in Al-Wusta province illustrated higher variations. This spatial pattern of distribution could be explained by the fact that most of Omani regions experience arid and semi-arid climate conditions that affect seasonal variability of water supply.

\subsubsection{Drought Severity Indicator}

The spatial pattern of drought risk is strongly associated with water quantity and availability. Drought severity mainly measures the mean of the reported drought events in a particular period of time. Areas with drought severity always experience higher degree of soil dray and multi-variation of precipitation deficit. The spatial pattern of drought severity across catchment basin within Omani provinces showed great heterogeneous distribution (Figure 6). In general, a distinguished pattern can be detected along the Omani coasts where the catchments basins exhibit lower score of drought. For instances, all coasts of A'Sharqiyah and Dhofar provinces display lower scores of drought. Similar pattern was found in most of Al-Batniah province. In contrast, drought score values increased in the areas that are located in a dray region and further away from the coasts such as internal catchment of Al-Wusta, Dhofar and A'Dakhiliyah. At province level, the lowest score of drought severity was observed in A'Sharqiyah and Masandam provinces while the highest scores were found in Al-Wusta and A’Dakhiliyah. Al-Batinah, Dhofar, A’Dhahriah and Muscat demonstrated a moderate value of drought.

\subsubsection{Flood Occurrence Indicator}

The geographic distribution of flood vulnerability levels could be an important indicator for surface water availability. Analyzing flood occurrence provides valuable information for water management and assessment of supply and demand. Evidently, flood events have a direct impact on various environmental domains in particular water quantity management. Flood occurrence measures the number of reported floods during a specific period of time. Figure 7 represents flood events in 4 decades across Sultanate of Oman by catchment and province. Surprisingly, catchment basins located in the interior regions showed higher values of flood occurrence compared with coastal areas. Thus, higher score of flood events was observed in Dhofar and Al-Wusta provinces. The moderate values were significant in A'Dakhiliyah, A'Dhahriah and A'Sharqiyah provinces. The pattern of low flood occurrence clearly was identified in Muscat, Al-Batinah and Masandam provinces. 

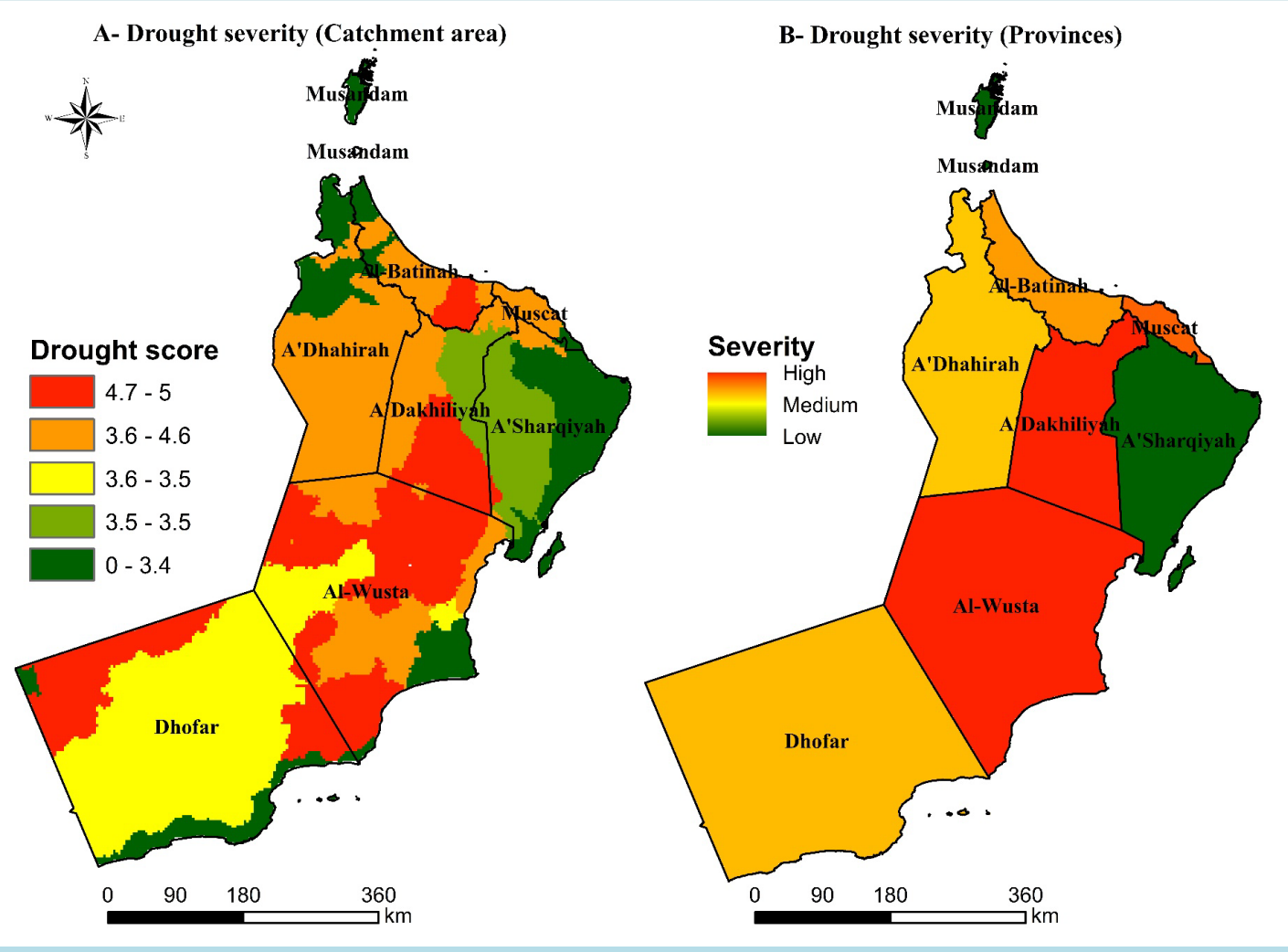

Figure 6. Variation in drought severity by catchment area and province.
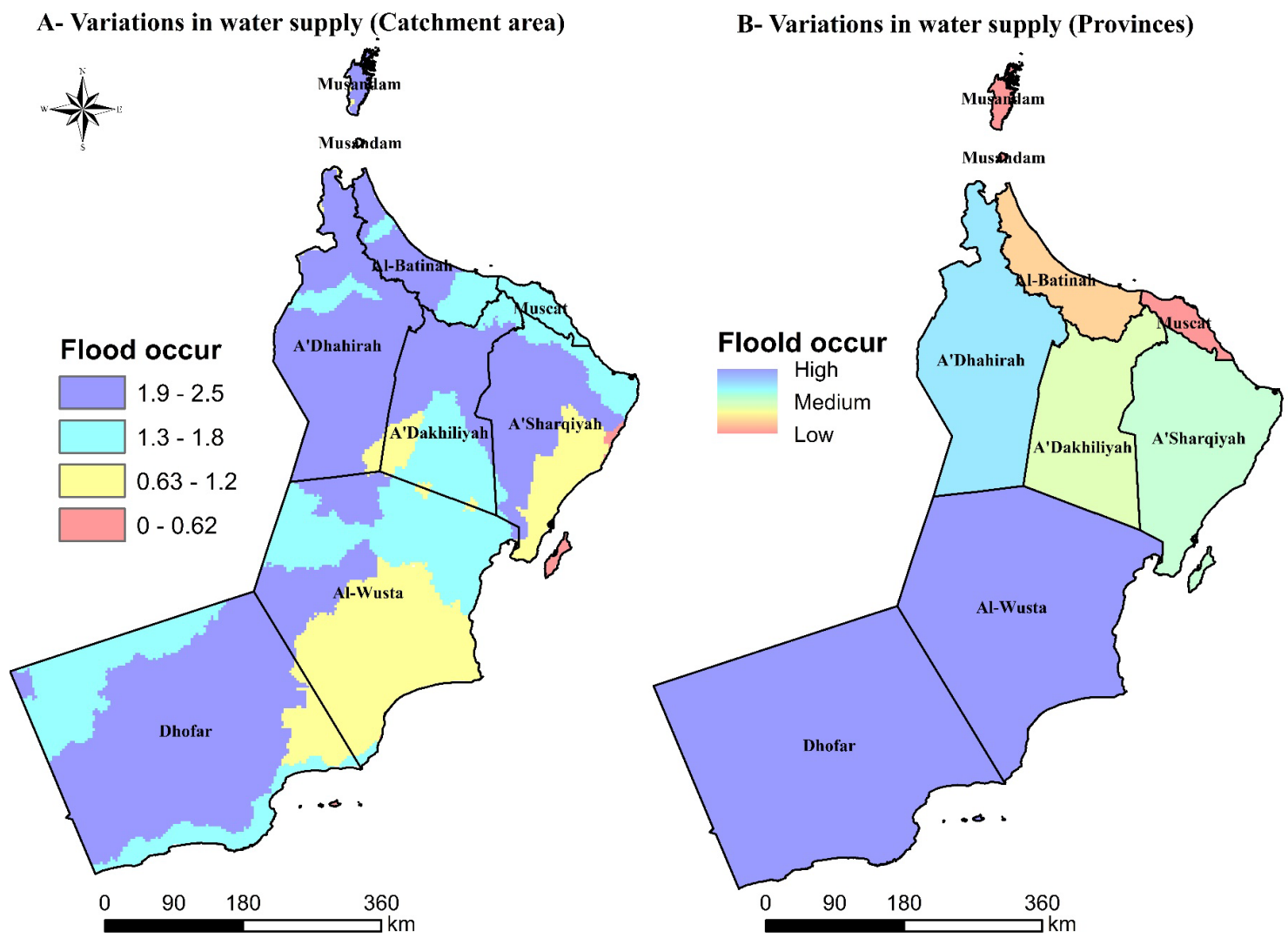

Figure 7. Variation inflood occurrence by catchment area and province. 


\subsection{Changes in Baseline Water Stress (BWS)}

Baseline water stress is the total water withdrawals to water availability ratio within a specific area. The indicator measures the total annual of water withdrawal for different usage such as domestic, agricultural and industrial. Higher scores indicate more competition among users while lower scores refer to a certain balance between water supply and demand. Figure 8 illustrates geographic distribution of this indicator across Omani catchments. Higher values of water stress are found in the areas that are located in the northern and eastern north parts of the country. These areas encounter water shortage and pressures and this might be investigated as the difference between water availability and consumption. These areas might exhibit intensity of water usage in several sectors which leads to higher rates of water abstraction (withdrawn water from various sources).The lowest rates of water abstraction are notably observed in the provinces with large arid areas such as Dhofar and Al-Wusta. In such places, the pressure on water resources is not significant because of the low population size and thus water usage is likely to be less intensive. With regard to the spatial distribution of baseline water stress at province level, Al-Batinah and Masandam provinces reported higher values of water stress. The same applies for Muscat province while lower values were found in A'Dakhiliyah and A'Sharqiyah. Figure 9 indicates a fairly significant correlation between water stress and seasonal variability in Omani provinces. This correlation suggests that seasonal variation of water supply is a crucial factor influencing both available water and abstraction volume in Oman.

\subsection{Water Quantity Risk (Exposure to Change in Water Quantity)}

The conceptual understanding of water risk assessment requires investigating the stress conditions that might have strong and significant effects on water quantity. Water quantity risk is defined as the exposure to change in water quantity. This index can be used to estimate the situation of water resources particularly supply, availability, reliability and demand. Figure 10 represents spatial distribution of water quantity risk over catchment and provinces. The highest risk scores were identified in most Muscat catchments. Higher scores also were observed in two catchments in the southern east of Al-Batinah and northern east of A'Dakhiliyah. Similarly higher scores

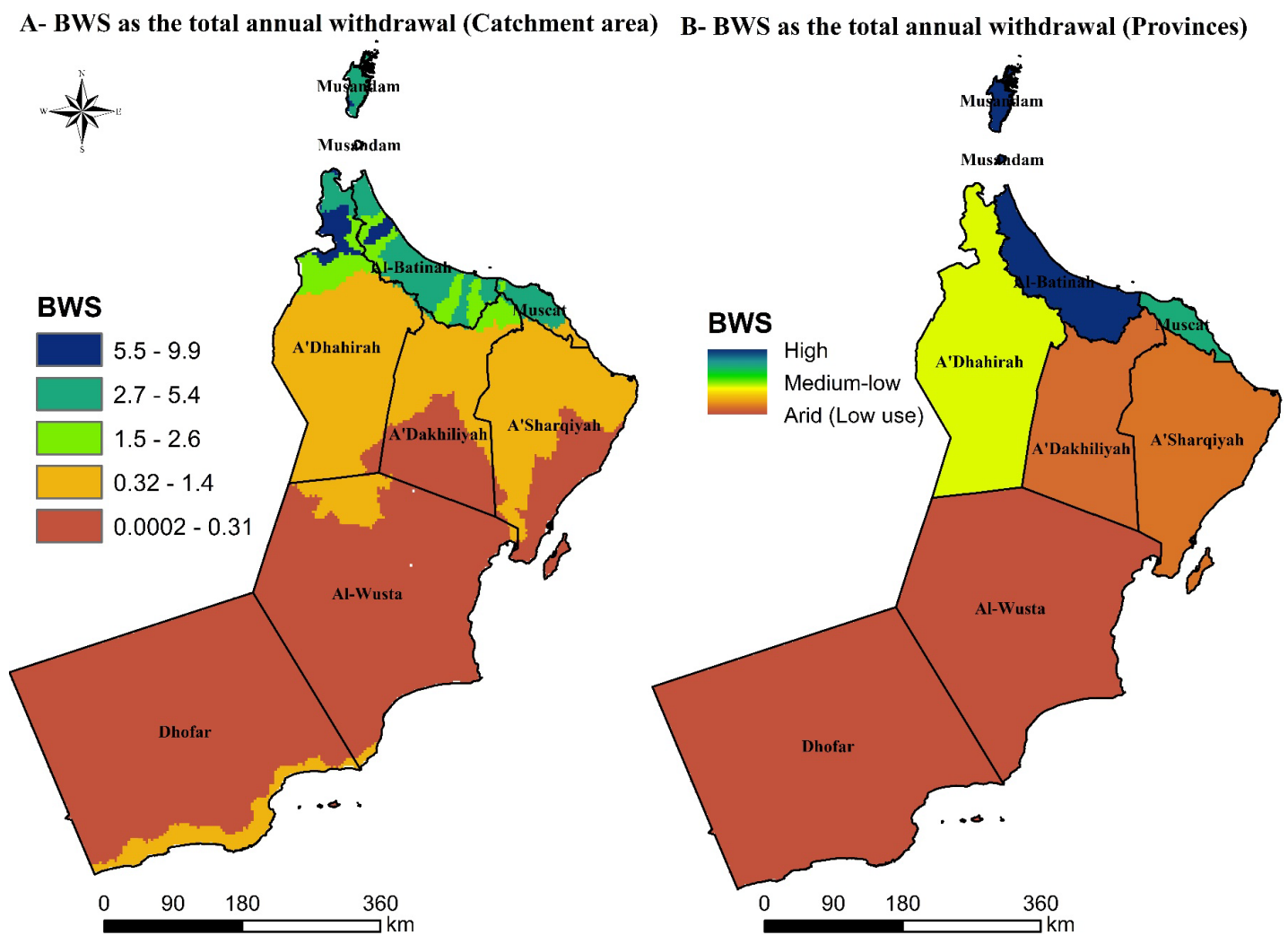

Figure 8. Changes in water stress by catchment area and province. 


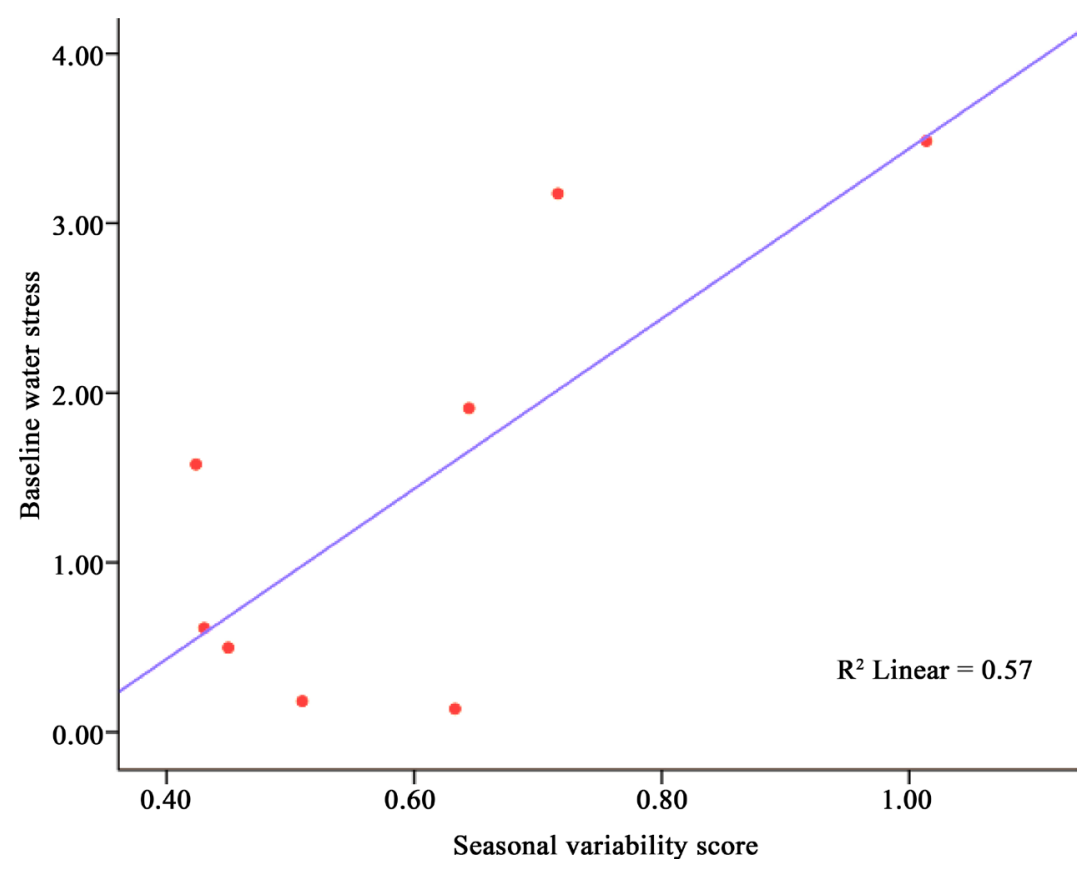

Figure 9. Correlation between BWS and seasonal variability across Omani provinces.
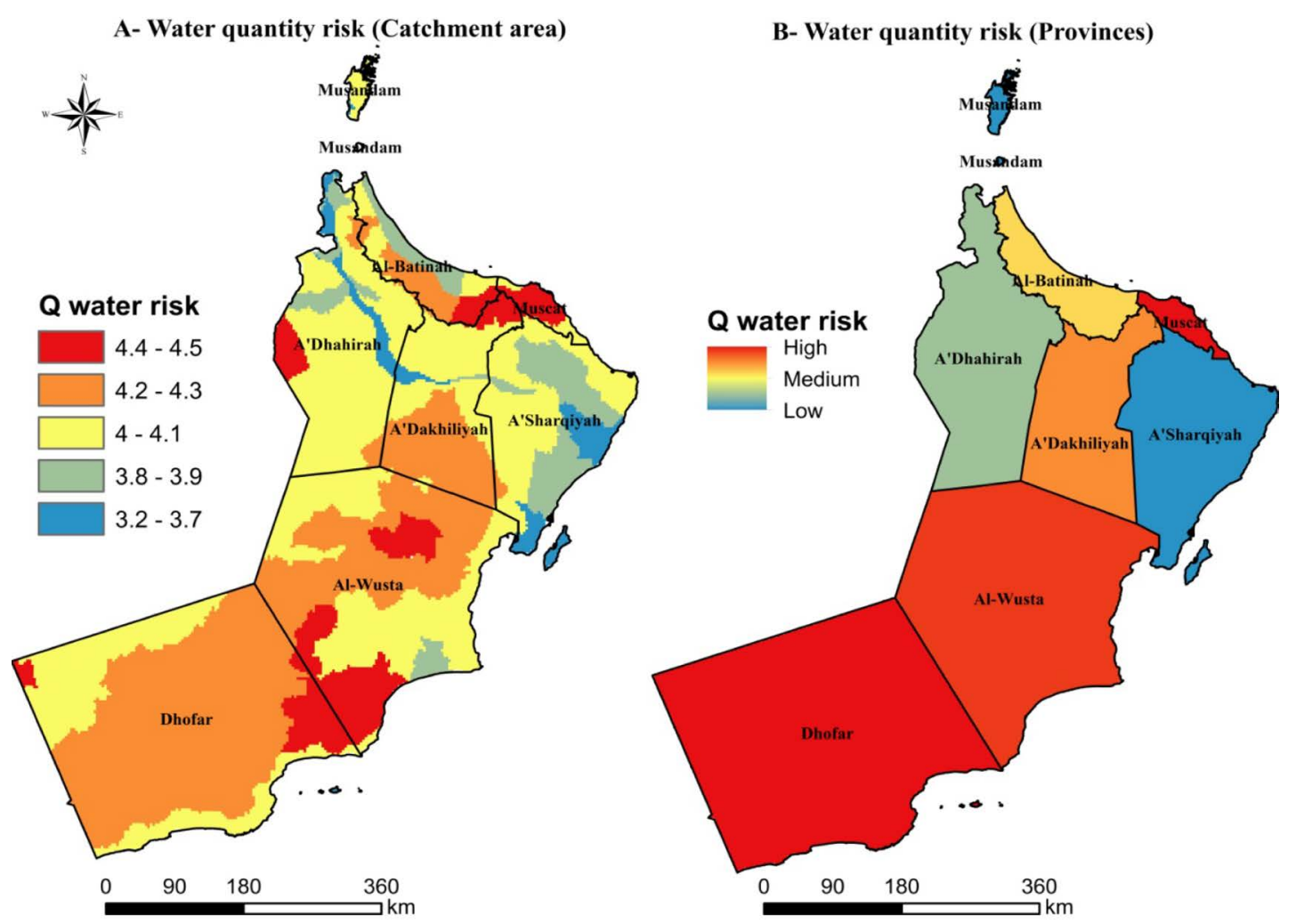

Figure 10. Spatial variation of water quantity risk by catchment area and province.

were found in several catchments in Al-Wusta and Dhofar provinces. On the other hand, water quantity risk decreased in A'Sharqiyah and A'Dhahriah provinces where these two governorates show the lowest risk values.

Among different combination of independent variable, the best fit model consists of these two variables as predictors for water quantity risk in the Omani provinces. The result of this regression model (Table 2) implies 
association between the response variables and the predictors. Furthermore, it indicated that the selected variables were significantly explaining approximately 79 percent of the variations in water quantity risk across the Omani provinces (adjusted $\mathrm{R}^{2}=0.786$ ). The model indicates a strong significant relationship between the dependent variable and the predictors (p-value is less than 0.05 ). The coefficient of the constant was 3.2 coefficients and for drought severity was 0.18 suggesting a positive impact on water quantity risk (Figure 11). Therefore, the null hypothesis stating that there is no linear relationship between water quantity stress and drought was rejected. Likely, the coefficient of seasonal variation was 0.28 and interestingly it shows a positive relationship with the dependent variable. Overall, the preliminary national variations of water quantity stress could be estimated using different environmental, climatic and hydrological predictors. However, among those explanatory variables, drought, flood and seasonal variation of water supply are the most significant factors affecting water quantity and explaining spatial variation of risk across the Omani provinces.

The findings indicated that water quantity risk was a function of various environmental and climatic variables in particular seasonal variation of water supply, flood occurrence and more importantly drought severity. The variation of water supply was higher in Al-Batinah, Muscat and Musandam while lower variation was identified in A'Dakhiliyah, A'Sharqiyah and A'Dhahriah provinces. The reported events of flood occurrence during 26 years indicated that Dhofar, A'Dhahriah, Al-Batinah and Al-Wusta exhibited larger number of flood events while A'Dakhiliyah and Muscat provinces showed lower number of floods. It is obvious that better understanding of drought severity distribution could help essentially in detecting risks associated with water availability. The finding of drought distribution also revealed that there was a distinguished pattern along the Omani coasts

Table 2. The outputs of regression analysis.

\begin{tabular}{cccc}
\hline Variables & Coefficient & t-test & p-value \\
\hline Drought severity & 0.1793033 & 5.26 & $0.003^{*}$ \\
Seasonal variation & 0.2745371 & 2.17 & $0.082^{* *}$ \\
Constant & 3.290887 & 19.16 & $0.000^{*}$ \\
\hline
\end{tabular}

Prob $>\mathrm{F}=0.0091$. R-squared $=0.84$. Adj R-squared $=0.7864$.

${ }^{*}=$ significant at 0.05 level; ${ }^{* *}=$ significant at 01 level.

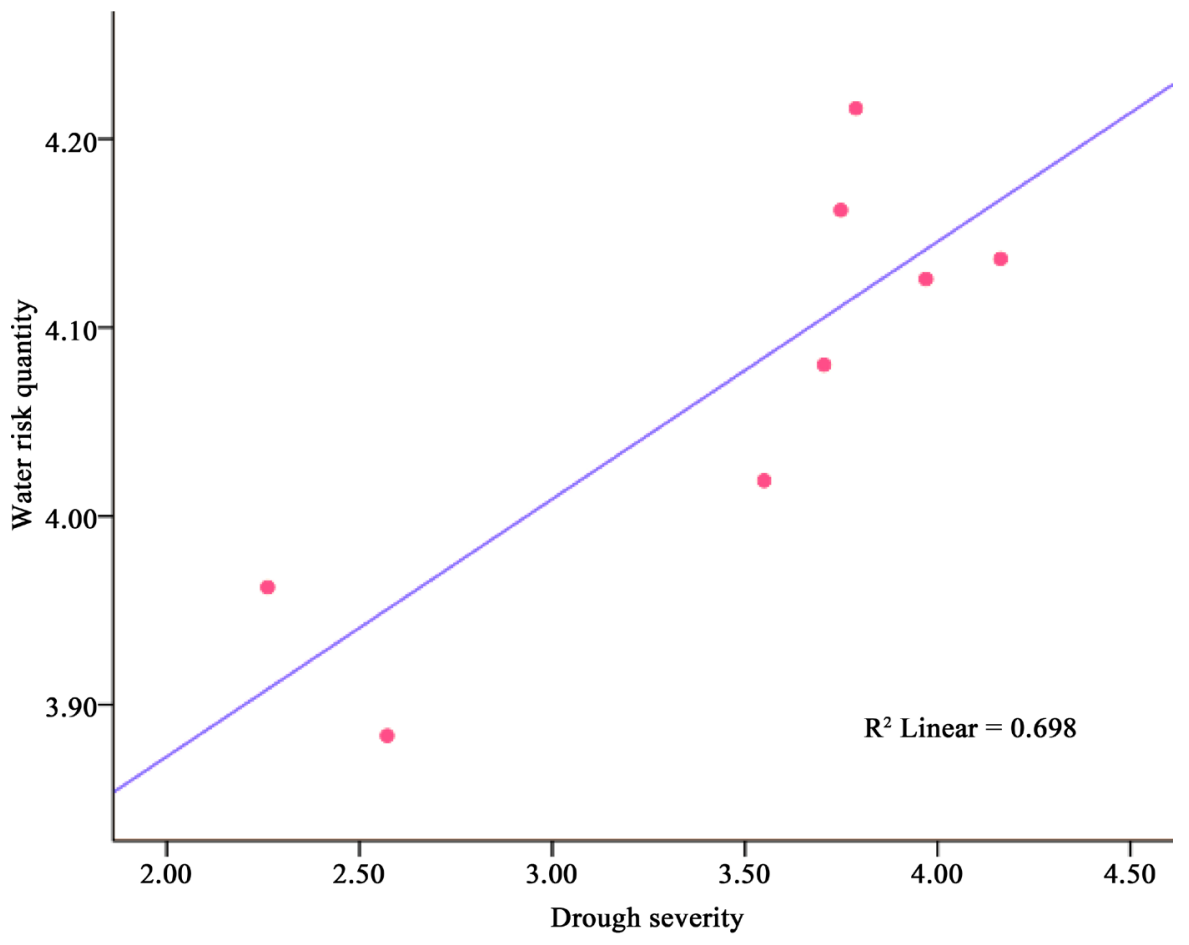

Figure 11. Correlation between risk of water quantity and drought severity across Omani provinces. 
where the catchments basins exhibited lower values of drought. In contrast to this pattern, internal places that are located in dray areas, further away from the coasts, illustrated higher values of drought specifically in Al-Wusta, Dhofar and A'Dakhiliyah.

\section{Conclusions}

Reviewing the literature, it was obvious that research on spatial variation of water quantity at national or subnational scale was very rare. In this study, an initial objective was to identify to what extent the influences of environmental factors on water quantity vary in Omani provinces. Clearly, an emphasis was placed on using GIS methods and statistical techniques to examine the spatial pattern of water quantity determinants. A multiple linear regression was fitted to estimate the degree of influence of each factor on water quantity risk in the Omani provinces. The larger and more significant predictors of water quantity risk were drought severity and seasonal variation of water supply. Initially, both variables explained approximately 79 percent of the spatial variation of water quantity risk. However, drought severity had direct impacts on water quantity risk and was significantly a strong predictor than seasonal variation of water supply.

Our study offers new insights into water stress assessment especially with regard to scope of managing water resources. Ultimately, this study contributes to understanding water scarcity problem in Sultanate of Oman and the findings can be an essential guide toward addressing the issues of the environmental effects on water resource management in the country. Considering climate change conditions and global water deficits, the geographic assessment at province level can lead to more effective utilization of all annual water supplies and abstraction in each province. In addition, it gives a broad spatial framework for reducing environmental risks to water quantity. Evaluating water resources at national and subnational scale could provide decision makers with better understanding of how to address the issues of water scarcity in each local administrative unit. Since the study was limited to aggregate data of water resources at province level, it was not possible to add more variables to the modeling analysis of environmental factors on water stress. However, in order to obtain a complete picture of water resources in the Omani provinces, other variables than environmental predictors have to be taken in account.

Further research on water quantity assessment in Sultanate of Oman using GIS and spatial analysis techniques is needed to develop effective water management strategies. Moreover, GIS analysis using additional ancillary data on water resources in each province would give a great opportunity to investigate spatial variations of water quantity. The valuable implications of such analysis are useful not only for managing water supplies but also in estimating future scenarios of water quantity required to be available for water usage sectors. To halt the negative trend of water scarcity in Sultanate of Oman, the government policies and plans for more sustainable water management in each Omani province should be based on incorporating integral spatial approaches into addressing availability and demand of water resources.

\section{References}

[1] Hoekstra, A.Y., Mekonnen, M.M., Chapagain, A.K., Mathews, R.E. and Richter, B.D. (2012) Global Monthly Water Scarcity: Blue Water Footprints versus Blue Water Availability. PLoS One, 7, e32688. http://dx.doi.org/10.1371/journal.pone.0032688

[2] Oki, T., Agata, Y., Kanae, S., Saruhashi, T., Yang, D. and Musiake, K. (2001) Global Assessment of Current Water Resources Using Total Runoff Integrating Pathways. Hydrological Sciences Journal, 46, 983-995. http://dx.doi.org/10.1080/02626660109492890

[3] Abdullaev, I. and Molden, D. (2004) Spatial and Temporal Variability of Water Productivity in the Syr Darya Basin, Central Asia. Water Resources Research, 40, 1-6. http://dx.doi.org/10.1029/2003WR002364

[4] Al-Adamat, R.A., Foster, I.D. and Baban, S.M. (2003) Groundwater Vulnerability and Risk Mapping for the Basaltic Aquifer of the Azraq Basin of Jordan Using GIS, Remote Sensing and DRASTIC. Applied Geography, 23, 303-324. http://dx.doi.org/10.1016/j.apgeog.2003.08.007

[5] Kummu, M., Ward, P.J., de Moel, H. and Varis, O. (2010) Is Physical Water Scarcity a New Phenomenon? Global Assessment of Water Shortage over the Last Two Millennia. Environmental Research Letters, 5, Article ID: 034006. http://dx.doi.org/10.1088/1748-9326/5/3/034006

[6] Qadir, M., Sharma, B.R., Bruggeman, A., Choukr-Allah, R. and Karajeh, F. (2007) Non-Conventional Water Resources and Opportunities for Water Augmentation to Achieve Food Security in Water Scarce Countries. Agricultural Water Management, 87, 2-22. http://dx.doi.org/10.1016/j.agwat.2006.03.018 
[7] Ragab, R. and Prudhomme, C. (2002) SW-Soil and Water: Climate Change and Water Resources Management in Arid and Semi-Arid Regions: Prospective and Challenges for the 21st Century. Biosystems Engineering, 81, 3-34. http://dx.doi.org/10.1006/bioe.2001.0013

[8] Vörösmarty, C.J., Green, P., Salisbury, J. and Lammers, R.B. (2000) Global Water Resources: Vulnerability from Climate Change and Population Growth. Science, 289, 284-288. http://dx.doi.org/10.1126/science.289.5477.284

[9] Iglesias, A., Garrote, L., Flores, F. and Moneo, M. (2007) Challenges to Manage the Risk of Water Scarcity and Climate Change in the Mediterranean. Water Resources Management, 21, 775-788. http://dx.doi.org/10.1007/s11269-006-9111-6

[10] Xu, Z., Ito, K., Schultz, G. and Li, J. (2001) Integrated Hydrologic Modeling and GIS in Water Resources Management. Journal of Computing in Civil Engineering, 15, 217-223. http://dx.doi.org/10.1061/(ASCE)0887-3801(2001)15:3(217)

[11] Santhi, C., Muttiah, R., Arnold, J. and Srinivasan, R. (2005) A GIS-Based Regional Planning Tool for Irrigation Demand Assessment and Savings Using SWAT. Transactions of the ASAE, 48, 137-147. http://dx.doi.org/10.13031/2013.17957

[12] Jayakrishnan, R., Srinivasan, R., Santhi, C. and Arnold, J. (2005) Advances in the Application of the SWAT Model for Water Resources Management. Hydrological Processes, 19, 749-762. http://dx.doi.org/10.1002/hyp.5624

[13] Awadallah, A.G. and Awadallah, N.A. (2014) An Integrated Water Resources and Economic Approach for Optimizing Water Allocation Policies. Journal of Water Resource and Protection, 6, 1444-1456. http://dx.doi.org/10.4236/jwarp.2014.615133

[14] Chen, D., Shams, S., Carmona-Moreno, C. and Leone, A. (2010) Assessment of Open Source GIS Software for Water Resources Management in Developing Countries. Journal of Hydro-environment Research, 4, 253-264. http://dx.doi.org/10.1016/j.jher.2010.04.017

[15] Parish, E.S., Kodra, E., Steinhaeuser, K. and Ganguly, A.R. (2012) Estimating Future Global per Capita Water Availability Based on Changes in Climate and Population. Computers \& Geosciences, 42, 79-86. http://dx.doi.org/10.1016/j.cageo.2012.01.019

[16] Alcamo, J., Flörke, M. and Märker, M. (2007) Future Long-Term Changes in Global Water Resources Driven by Socio-Economic and Climatic Changes. Hydrological Sciences Journal, 52, 247-275. http://dx.doi.org/10.1623/hysj.52.2.247

[17] McKinney, D.C. and Cai, X. (2002) Linking GIS and Water Resources Management Models: An Object-Oriented Method. Environmental Modelling \& Software, 17, 413-425. http://dx.doi.org/10.1016/S1364-8152(02)00015-4

[18] Aspinall, R. and Pearson, D. (2000) Integrated Geographical Assessment of Environmental Condition in Water Catchments: Linking Landscape Ecology, Environmental Modelling and GIS. Journal of Environmental Management, 59, 299-319. http://dx.doi.org/10.1006/jema.2000.0372

[19] Vörösmarty, C.J., Douglas, E.M., Green, P.A. and Revenga, C. (2005) Geospatial Indicators of Emerging Water Stress: An Application to Africa. AMBIO: A Journal of the Human Environment, 34, 230-236. http://dx.doi.org/10.1579/0044-7447-34.3.230

[20] Stempvoort, D.V., Ewert, L. and Wassenaar, L. (1993) Aquifer Vulnerability Index: A GIS-Compatible Method for Groundwater Vulnerability Mapping. Canadian Water Resources Journal, 18, 25-37. http://dx.doi.org/10.4296/cwrj1801025

[21] Tanriverdi, C. (2010) Improved Agricultural Management Using Remote Sensing to Estimate Water Stress Indices. Applied Remote Sensing Journal, 1, 19-24.

[22] Al-Ansari, N.A. (2013) Management of Water Resources in Iraq: Perspectives and Prognoses. Engineering, 5, 667-684. http://dx.doi.org/10.4236/eng.2013.58080

[23] Murad, A.A., Al Nuaimi, H. and Al Hammadi, M. (2007) Comprehensive Assessment of Water Resources in the United Arab Emirates (UAE). Water Resources Management, 21, 1449-1463. http://dx.doi.org/10.1007/s11269-006-9093-4

[24] Al-Rashed, M.F. and Sherif, M.M. (2000) Water Resources in the GCC Countries: An Overview. Water Resources Management, 14, 59-75. http://dx.doi.org/10.1023/A:1008127027743

[25] Abdel Rahmnn, H.A. and Omezzine, A. (1996) Aflaj Water Resources Management: Tradable Water Rights to Improve Irrigation Productivity in Oman. Water International, 21, 70-75. http://dx.doi.org/10.1023/A:1008127027743

[26] Reig, P., Shiao, T. and Gassert, F. (2013) Aqueduct Water Risk Framework. Working Paper, World Resources Institute, Washington DC. http://www.wri.org/publication/aqueduct-water-risk-framework 